\title{
SPECIAL KINDERGARTENS: DOES THE RISK OF BURNOUT DEPEND ON THE PROFESSION?
}

\author{
Zuzana Truhlářová ${ }^{1}$, Jana Marie Havigerová ${ }^{1}$, Tamara Pokorná ${ }^{1}$ \\ ${ }^{1}$ Institute of Primary, Pre-primary and Special Education, Faculty of Education, University of Hradec Králové, \\ Rokitanského 62/26, 50003 Hradec Králové (CZECH REPUBLIC)
}

\author{
Eduport 5 (2) - Reviewed Papers \\ DOI: $10.21062 /$ edp.2021.010
}

\begin{abstract}
The aim of the study was to determine the prevalence of burnout syndrome and analyse professional contexts u professional workers of special kindergartens. Research tool: online survey in the range of $11+21$ items, the first part of own construction, second part a standardized Burnout Measure questionnaire. Basic sample: there were 6 special kindergartens within Hradec Králové region in January 2021, the basic sample consisted of 51 professional workers. The questionnaire was filled by in a total of $\mathrm{N}=33$ professional workers of special kindergarten schools (returned 64,7\%), special teachers $N s p=18$, teacher's assistants $N a p=15$, at the age of 18 up to 65 years, with a length of practice 1 up to $>20$ years. With one exception, all respondents are women. The results show, that $2 / 3$ of respondents are at a level of complete or partial mental health, $1 / 4$ of respondents are at a level of mild burnout risk and only $6 \%$ of respondents show the presence of mental exhaustion syndrome and is in a condition that requires a treatment. Furthermore, the results show, that there is a statistically proved difference between the level of burnout syndrome and a profession $(W=150, p<0,05)$, teacher's assistants are more endangered (on a five-level scale of they reach mean ${ }_{a p}=2,6 \pm 1,05$, versus means $\mathrm{sp}_{\mathrm{sp}}$ $=1,9 \pm 0,67)$, they are independent at the level of experience $(W=108, p=0,341)$. The correlation coefficient points out at a statistically significant close relation between the level of burnout syndrome and the respondent's age ( $r$ o $=0,403, p<0,05$ ), however, is independent on the length of the field's practice (rho = $0,135, p=0,452$ ). Because teacher's assistants are younger on average, age can be a moderator of a relation between the profession and the level of burnout syndrome. The results show, that in special kindergartens there must be the risk of burnout syndrome considered, paradoxically in mainly younger and starting teacher's assistant and to provide sufficient support for beginning professionals, especially during the adaptation phase.
\end{abstract}

Keywords: special kindergarten, teachers, teacher's assistants, burnout syndrome

\section{INTRODUCTION}

Burnout syndrome among teachers and pedagogical workers has been currently a major issue, which can be identified also in the field of pre-school preparation of children with specific learning educational needs (De Stasio \& all.,2020, Smetáčková, 2019). A long-term exposure of stressful factors in a work place can predict negative side effects in helping professions, i.e. not just pedagogical workers in their lives and work. Which can lead to a reduction of their quality of lives and as a result also to a deteoriation in the quality of teaching (Jeung \& all, 2018; De Stacio \& all, 2017; Mahmoodi-Shahrebabaki, 2018, Carson, Plemmons, Templin, \& Weiss, 2011). Burnout syndrome is defined as a syndrome of emotional exhaustion, depersonalization and reduced performance, that can occur in individuals working in helping professions. It represents a long-term response to chronic emotional stress and interpersonal stress at work. (Darius et al. 2021; Schonfeld \& Bianchi, 2016; Maslach, 2015)

Pines \& Keinan (2002) identify the burnout syndrome as a result of a gradual disillusionment, that arises from an action of several- exhaustion, emotional overload and a feeling of personal failure associated with reduced performance. According to existential perspective the basic cause of burnout syndrome lies in the people's need to believe that their life, work has a sense, that things which they are useful and important. The question of the meaning might be primary for the teaching profession and crucial in case of a loss or doubt about its 
significance. Feelings, that they had failed, that their work is insignificant, that nothing would change, helplessness and hopelessness are the cause of burnout syndrome (Pines, 2002).

Sinclair, Dowson \& Mclnerney (2006), Zelinková (2014) distinguish motives for performing the teaching profession on internal adaptive (interest in working with children; the need to educate, pass on experience, shape young people; the desire for constant self-education; the need to pursue respected education), external adaptive (young environment - the opportunity to stay mentally young; freedom and creativity, that is connected with teaching profession)and external maladaptive (decision making according to friends, classmates, peers, a parent pattern, relative, teacher; plenty of free time). These expectations are often not met in school teaching practice. Subjectively, perceived job satisfaction/dissatisfaction is a significant predictor for development of burnout syndrome (Robinson et al., 2019) Pedagogical workers ${ }^{1}$ solve dilemmatic situations confronting their expectations, ideas and motivation, which can be one of the factors, that be identified as a possible cause of burnout syndrome. This issue is very noticeable in the pre-school preparation of children (Darius et all., 2021; Clipa \& Boghean,2015). Another significant factor influencing the development of burnout syndrome is the length of practice. (Aboagye \& all, 2018; Sinclair \& Dowson Mclnerney, 2006; Carson \& all., 2011; Zelinková, 2014; Pines \& Keinan, 2005). Education of children with special educational needs requires greater burden on carers, teachers and other helping professions, that result from a child's disability. The individual's disability and the specifics of approaches and the needs associated with that can be a significant indicator of the perceived burden and another possible cause of the burnout syndrome (Levicka, J. et al. 2018; Truhlářová et al., 2020; Ji \& Yue, 2020; Tasic et al.2020)

Ji \& Yue (2020) draw attention to the fact, that kindergarten teachers are also burdened by the direct care of pre-school children and their needs, and are also under a great pressure from the children's parent side and their expectations.

In the Czech Republic, in the field of pre-school preparation of children with special educational needs, according to the Act on Pre-school, Primary, Secondary, Higher vocational and other education (School Law) ${ }^{2}$ the kindergartens are set up according to $\S 16$, article 9 "for children, pupils and students with mental, physical, visual or hearing impairments, severe speech impairments, severe learning disabilities, severe behaviour disorders, multiple disabilities and autism, may be established in schools or classrooms, departments and study groups... "These schools focus on the education of children, who, due to their state of health, require specific forms of education - individual approach, specific methods of educational work, specialized procedures, didactic material, socio-therapeutical approaches, rehabilitation and supportive social services. Under the guidance of a teacher, the teacher's assistant assists during education of children with special educational needs and implements a support of pupils' activities in the school facility. ${ }^{3} \mathrm{~S} /$ he cooperates with a teacher and is a support for the child with health disability in school preparation. $S /$ he is in a direct interaction with the child, most common activities are verbal, eye support for the child, repeated explanations, assistance in adapting to kindergarten (assistance in developing social skills, orientation in space and time, conflict resolutions), helping the child in communication and establishing social relationships, mediation of communication between family and kindergarten, assistance in creating and developing work and hygiene habits, providing a supervision and rest, assistance to teachers with the preparation of teaching aids and material, cooperation in creating, implementing, correction and supplementing an individual educational plan. (Němec at al. 2015; Kendíková, 2016; Sheridan, Reeve \& Evans, 2014)

Smetáčková (2019) points out, that burnout teachers often experience a worsening of the pedagogical process as a result the burnout syndrome, poor teaching, insensitivity of pupils' needs, inadequate responses to situations arising from the pedagogical process and problems within the work team. A research survey which was conducted in the year 2019 within kindergartens in the Czech Republic, show that out of 867 female and male teachers and female and male teachers' assistants of kindergartens $79 \%$ of the respondents reported burnout syndrome values $15 \%$ of them already reported an existing burnout. Similar results are confirmed by Darius et al. (2021) in his study, where 200 kindergarten teachers participated, and he identified the incidence of burnout syndrome in $4,5 \%$ and $34 \%$ of respondents the burnout syndrome signs were detected.

Chrzanowska (2019) points out in her study, that pedagogical workers who work with children with special educational needs face greater demands on their professional competences and are exposed to high workloads. Education of children with specific educational needs require a higher level of burden resulting from

\footnotetext{
${ }^{1}$ For the purpose of this study, specified as teachers and teaching assistants.

2 Act on Pre-school, Primary, Secondary, Higher education and other educaiton and about changes of some Acts (School Law). No. 561/2004 Coll. as amended. $\$ 16 /$ article 9

${ }^{3}$ It is regulated by a Decree No. 248/2019 Coll., amending the Decree No. 27/2016 Coll. on Education of pupils with special educational needs and talented pupils, as amended, and a Regulation No. 72/2005 Coll. on Providing counseling services in schools and school counselling centres, as amended by Article 1
} 
the specific child's health disadvantages. The individual's disability and specifications, that come with, might be a significant indicator of the perceived burden, confirmed by Truhlářová at al., 2020; Ji \& Yue, 2020; Tasic et al., 2020.

In our study we focus on a detection of burnout syndrome occurrence in teachers and teachers 'assistants in kindergartens (according to $\$ 16 /$ article 9 School Law), educate children with special educational needs. These two work positions are a very important part within the system of education of pre-school children in kindergarten and are interested in, whether burnout syndrome occurs in these pedagogical workers, whether any of these jobs are more vulnerable, and whether factors (the length of practice, age) are associated with the occurrence with burnout syndrome.

\section{Aim of study}

The aim of the study is to find out prevalence of burnout syndrome and to analyse professional context in professional workers (teachers and teachers' assistants) in kindergartens (according to $§ 16 /$ article 9 School Law).

Partial goals are:

a) to identify burnout syndrome prevalence (descriptive part),

b) to find out, whether there is a relation between the level of burnout syndrome and time variables and the length of practice (comparative study),

c) to find out, whether the level of burnout syndrome is different in connection with a profession (comparative study).

\section{METHOD}

The aim of the study was to find out the prevalence of burnout syndrome and to analyse professional context of professional workers in special kindergartens. The study has a character of CAWI quantitative research.

\section{Materials}

A quantitative research strategy had been chosen to solve research goals, the research technique is a questionnaire consisting of two parts: sociodemographic part (detects profession, age, gender, the length of practice), questionnaire Burnout Measure (21 items).

Burnout Measure questionnaire (in Křivohlavý, 1998, p. 37-39) is a standardized questionnaire, which determines a level of mental burnout (burnout quotient BQ). The questionnaire consists of 21 statements, where respondents evaluate on a scale 1 (never) up to 7 (always). Questionnaire Data is processed by a conversion to auxiliary values $A-D$ (values $B=i 3+i 6+i 19+i 20, A=$ sum of other items, $C=32-B, D=A+C$ ), where is $a$ value of a burnout level:

\footnotetext{
1. good result in terms of mental health $(B Q<42)$;

2. result is still satisfactory $(42<B Q<63)$;

3. is recommended to think about the lifestyle, the feeling of meaningfulness of life $(63<B Q<84)$;

4. presence of mental exhaustion syndrome $(84<\mathrm{BQ}<105)$;

5. alarming condition, suitable to seek professional care from a psychologist or psychotherapist (BQ $>105)$.
}

The references refer to very good psychometric properties of the questionnaire: the value of internal consistency of the inventory varies from $r=.90$ higher, test-retest reliability in spacing 1 up to 4 months ranges from $r=.66$ up to $r=.89$, construct validity was demonstrated by clinical investigations and correlations with relevant variables (Pines \& Aronson, 1988). Kebza \& Šolcová (2008) performed a factor analysis study and found out that all items were saturated with a single factor, which explains ca $70 \%$ variance; they call the factor exhaustion. We verified the psychometric properties of the questionnaire on our data. Tests for internal consistency ratios were computed: McDonald's $\omega=0.891$ a Cronbach's $\alpha=0.856$ indicates a high degree of inner consistence. We have verified this fact on our data: exploratory factor analysis with oblique rotation Oblimin shows only one factor, whereas three items have negative factor value (item 3 "I feel like having a 
good day", item 19 "I feel optimistic" and item 20 "I feel energetic"), value of a factor item 0.4 was not exceeded by any single item (item 6 "I feel happy.").

\section{Data processing procedure}

Data file had been downloaded from online environment survio. A recording of verbal ordinal scales to numerical expressions (e.g. at the item age the intervals were converted to values 1-5).

The length of practice was converted bipolar for the comparative study: practice $\leq 5$ let $=$ beginner, practice $>5$ years $=$ expert (categories derived from the theory of expertise development, see e.g. Nur \& Seung-II, 2020).

Table 1 Level of expertise: contingency table ( $N=33)$

\begin{tabular}{llcc}
\hline Profession & beginner & expert & Total \\
\hline teaching assistant & 8 & 7 & 15 \\
special pedagogue & 6 & 12 & 18 \\
Total & 14 & 19 & 33 \\
\hline
\end{tabular}

Both groups are in terms of specialization and expertise significantly mutually balanced $\left(X^{2}=1.340, d f=1, p=\right.$ 0.247).

The auxiliary scale A-D was calculated and the BQ level was determined for each respondent.

Furthermore, descriptive statistical data were calculated and assumptions for further calculations were verified. The normality of the layout (Mogorov-Smirnov test) has not been confirmed, therefore nonparametric versions of the chi-square test and t-test are further processed (Klotz, 1963).

\section{Procedure}

The generated questionnaire was applied in the online system survio.cz. All special kindergartens in Hradec Králové region (Kindergarten Slunečnice, DANETA, Kindergarten Trutnov, Kindergarten and Practical Primary school NONA and Kindergarten Letná) were sent by an email requesting that the questionnaire shall be forwarded to all employees meeting the inclusion criteria (profession of a social worker or a teacher's assistant), the request was supported by phone call with the management deputy from the above addressed kindergarten and with an explanation of the study objectives, ethical rules and with the promise to deliver statistically processed results to support decision-making. The questionnaire was launched on $1^{\text {st }}$ January 2021 and by the end of the month was closed. It took the respondents 10-21 minutes to complete the questionnaire.

\section{Participants}

The research was focused on a population of social pedagogues and pedagogue's assistants in special kindergartens. The basic group consists of all special pedagogues and teaching assistants in special kindergartens in Hradec Králové region. A total of 51 respondents had been sent a link to an online questionnaire in January 2021, Sampling method: self-selection. A total of 33 completed questionnaire were obtained, i.e. return $64,7 \%$. A composition of the research sample: there were 32 women and only 1 man (for that reason, we have given up on the originally planned assessment of gender differences), of which there were 18 special pedagogues and 15 pedagogues's assistants at the age of 18-65 years.

Table 2 Respondents': descriptive statistics ( $N=33$ )

\begin{tabular}{lll}
\hline Age & Frequency & Percent \\
\hline$<20$ & 2 & $6,06 \%$ \\
$21-35$ & 13 & $39,39 \%$ \\
$36-50$ & 10 & $30,30 \%$ \\
\hline
\end{tabular}




\begin{tabular}{lll}
\hline $51-65$ & 8 & $24,24 \%$ \\
Total & 33 & $100,00 \%$ \\
\hline
\end{tabular}

\section{RESULTS}

Prevalence of burnout syndrome in professional workers of special kindergartens was determined by descriptive statistic. Frequency analysis (table 3 ) shows, that approximately $2 / 3$ of respondents evince a good and satisfactory result (level 1 and 2), approximately $1 / 4$ of respondents show a result requiring reflection (level 3 ) and only $6 \%$ of respondents evince the presence of burnout syndrome and an alarming status (level 4 and 5).

Table 1 BQ levels: descriptive statistics ( $N=33)$

\begin{tabular}{lrrrr}
\hline BQ levels & Frequency & Percentage & \multicolumn{1}{c}{$\begin{array}{l}\text { Cumulative } \\
\text { Percent }\end{array}$} \\
\hline & 1 & 7 & 21.212 & 21.212 \\
& 2 & 15 & 45.455 & 66.667 \\
& 3 & 9 & 27.273 & 93.939 \\
& 4 & 1 & 3.030 & 96.970 \\
& 5 & 1 & 3.030 & 100.000 \\
Total & & 33 & 100.000 & \\
\hline
\end{tabular}

The relation between the level burnout syndrome and variables length of practice and age had been tested by calculating the Spearman correlation coefficient, where we test against null hypothesis talking about a zerocorrelation coefficient. The correlation coefficient indicates a statistically significant close relationship between the rate of burnout syndrome and the respondent's age (rho $=0,403, p<0,05$ ). This relation is not only significant at the appropriate level of significance, but also according to de Vause (2002) is a moderate to substantial addiction. Among authors, among who is possible to talk a moderate addiction, are Cohen (1988), Hendl (2012) or Chráska (2016). In terms of the coefficient determination value, this value explains approximately $16 \%$ and the rest of $84 \%$ can be attributed to other influences (more in Soukup, Trahorsch \& Chytrý, 2021). In case of the length of practice these conclusions differ (rho $=0,135, p=0,452$ ). Therefore, it is not possible to generalize the conclusion, there is also a small dependence with a low value of coefficient determination.

Whether the level of burnout syndrome varies depending on profession (special pedagogues vs. teacher's assistant) was tested by the Wilcoxon test to compare to individual groups see Table 4 . Result values (W $=190$, $\mathrm{p}<0.05$, Rank-Biserial Correlation $=0.407$ ) indicate, that there is a statistically significant difference in $B Q$ level between two tested professional groups.

Table 2 Relation between BQ level and profession: descriptive statistics ( $N=33)$

\begin{tabular}{llcccc}
\hline & Group & N & Mean & SD & SE \\
\hline BM_CAT_II & teaching assistant & 15 & 2.600 & 1.056 & 0.273 \\
& special pedagogue & 18 & 1.889 & 0.676 & 0.159 \\
\hline
\end{tabular}

Table 4 shows, that the group teaching assistant has a higher $\mathrm{BQ}$ level on an average, than the group of teachers. Teachers reached on average values 1,8 , which means, that they range, on an average between mental and a satisfactory outcome, whereas teaching assistants reached average values 2,6, which means, that they approach to a category where is recommend to reflect on a lifestyle and the sense of meaningful life - we 
can predict, that the syndrome of mental exhaustion is not yet present, but respondents receded further from the mental health. Which means, that teaching assistants show a higher level of burnout than teachers.

\section{DISCUSSION}

The study had three goals, the obtained evidence leads to the following statistic-based conclusions: (1) The goal to identify prevalence of burnout syndrome. It was found, that among the workers of special kindergartens, there is approximately one third are at the risk of burnout syndrome: $27 \%$ of professional employees is in a moderate danger and $6 \%$ of employees are in a direct risk of burnout syndrome. (2) To determine, whether there is an existing link between the level of burnout syndrome and time variables. The results showed, that the length of practice is not statistically demonstrably associated with the risk of burnout ( $r$ ho $=0,135, p=0,452$ ), i.e. in principle, new employees are in the same danger, as resident employees burnout syndrome can affect anyone. On the contrary, a moderately close association was demonstrated between the burnout syndrome and the age of respondents (rho $=0,403, p<0,05$ ), which show, older the worker is, the more s/he is at risk of burnout. (3) To find out, whether the level of burnout syndrome varies depending on the profession, which the person in the special kindergarten holds. The results showed, that the group is demonstrably more endangered by the burnout syndrome $(W=190, p<0.05)$, than the group of special pedagogues.

Burnout syndrome in pedagogical staff demonstrably endangers not only their quality of life and health, but also affects their work performance, relationship to pupils and quality of their teaching lessons (Kokkinos, 2007; Smetáčková,2019; Mahmoodi-Shahrebabaki,2018). Research study of Chrzanowska (2019), Aboagye et al. (2018), Darius et al. (2021) identified the occurrence of burnout syndrome in teachers of pre-school preparation of children in kindergartens. Thus, we had predicted, that teachers and teaching assistants working in kindergartens preparing for school attendance for children with special educational needs would have been diagnosed with burnout syndrome, and our data confirmed this prediction. Within our research study, we found out in tested teachers and teaching assistants in kindergartens, that $2 / 3$ of respondents are in their results at the level of complete or sufficient mental health , $1 / 4$ of respondents are at the level of a mild risk of burnout syndrome and as many as $6 \%$ of respondents show the presence of mental exhaustion syndrome and are in a condition that requires a solution. The determined percentage distribution of the burnout syndrome threat in the researched sample of respondents is confirmed by results of studies by Darius et al. (2021), Aboagye et al. (2018), De Stasio et al. (2017). This points to the possibility, that up to $30 \%$ of teachers are primarily at risk of burnout syndrome, of which $5-10 \%$ already have burnout symptoms.

A kindergarten teacher and a teacher's assistant have other pedagogical competences in the process of education (Němec, Šimáčková-Laurenčíková \& Hájková, 2014). Thus, it was assumed that these two groups would have different burden with the burnout syndrome, i.e. that there would be a difference between the burden and the profession. This assumption has been confirmed. We have found out a statistically significant correlation between the burnout level and a profession, in our study. We have identified, that teaching assistants indicated to be more at risk of burnout syndrome than teachers themselves.

There is an interesting fact, that the relation between the burnout level and the years of practice has not been confirmed. It turns out, that the time of practice does not have to bet he factor, which is significant for the level of burnout occurrence. This contradicts the findings to some extent of Aboagye\& all, 2018; Sinclair \& Dowson Mclnerney, 2006; Carson \& all., 2011; Zelinková, 2014; Pines \& Keinan, 2005, who identified the time length of practice as one of the factors influencing the level of burnout syndrome. However, our study has confirmed the significance between the burnout level and the respondent's age. Because the respondents - teaching assistants were younger, on average, than teachers, age can bet he moderator of the relation between the profession and the level of burnout. The results show, that in special kindergartens is necessary to consider the burnout risk paradoxically, mainly in younger and starting teaching assistants and to provide them, especially in the adaptation phase.

The results of the study may be affected and limited by several aspects inside and outside the study - (A) sample size, (B) sample selection, (C) used research tool and (D) current geopolitical consequences.

(A) The presented study is unique in the Czech Republic, because it maps the incidence of the burnout syndrome in kindergarten teachers and teaching assistants, who focus on pre-school preparation of 
children with disabilities. The limit of the study is the fact, that implemented in a small sample of respondents in absolute terms (the number of participants does not allow to work with randomness, some more sophisticated statistical procedures etc.). On the other hand, the sample represents $92 \%$ of all special kindergartens in region of Hradec Králové, which entitles to generalize this region.

(B) The profession was the indicator of the selections of the respondents - teachers and teachers 'assistants in kindergartens focusing on education of children with specific needs. Although the selection of the given sample is not representative, but it reflects the distribution within the representation of the monitored professions and represents the majority of the basic set (complete special kindergartens within the region). However, the limit can be a sampling method - it is a matter of self-selection: it results, that individuals, who were did not engage in the research, could have had some characterises, that remained hidden from the research.

(C) The questionnaire which the respondents filled in the online environment was used as a research tool. The limitation of this technique was, that the respondents filled the questionnaire without any assistance, so they might not have understood the perceived situation correctly and used a wrong evaluation. We perceive the risk of distortion in this case as small, because they are adults, professionals in their field, the items had been piloted and had been assessed as understandable.

(D) Kindergartens focusing on the pre-school preparation of children with special educational needs were closed or significantly reduced at a time of data collection, due to Covid measures within the Czech Republic. This fact could have affected both the respondents' own feelings (unusual situations, danger etc.), as well as the willingness to participate in the research.

Future research should focus on the issue of burnout syndrome in teachers and teachers' assistants in more details. In subsequent research, it would be appropriate to examine relation with age in more depth (not as expected with the length of practice). Furthermore, it would be undoubtably desirable, to extent research attention to the field of coping strategies and stress management, together with the impact of psychosocial support of teachers on burnout level and a focus on measuring the effectiveness/efficiency of selected intervention strategies, that could reduce the incidence of burnout syndrome in teachers and teachers 'assistants in special kindergartens.

\section{CONCLUSION AND IMPLICATIONS}

The research results confirm the expected prevalence of burnout syndrome in teachers and teaching assistants in special kindergartens ( $6 \%$ is directly at risk of burnout syndrome). It turns out, that its level of incidence is influenced by the profession: teaching assistants are more at risk of the burnout syndrome than teachers themselves. The age, is another significant factor that indicates an important level of burnout (older the worker is, more is at risk, not matter the number of years spent in that concrete profession), therefore is important not to neglect mental care of older professional workers of special kindergartens.

Therefore, we should prevent from burnout syndrome as part of primary prevention. It is important to focus on psychosocial and mental support all of professional professions in a pedagogical process as soon as they enter the work process, especially the support and training of young teaching assistants, as assistants are more vulnerable. Darius et all. (2021), Nur, \& Seung-Il (2020), Baran \& al. (2010) point out at the importance of support and motivation of personal development and education in teachers. This concept is necessary to apply and implement also in teachers' assistants. To strengthen the process of professional preparation of teaching assistants and to support their personal development also in their pedagogical practice (Teplá, Felcmanová, \& Němec, 2019; Pavlidou, Alevriadou \& Antoniou,2020; Darius et all., 2021). This process should start as soon as they start working on a teacher's or a teaching assistant's position during his/her professional growth in a concrete kindergarten. Intervention programmes for teachers and teaching assistants and educational activities, which are aimed at strategies to decrease psychosocial distress, emotional and spiritual support, stress management methods and techniques and psychotherapeutic support, should be implemented into practice. (Tasic et al., 2020)

To motivate teachers in participations in these programs is highly essential. Another interesting tool for burnout prevention can be the use of supervision as a psychosocial support for educators. This can be targeted to a supervision of an educational process, as well as to the supervision work team. It represents an effective tool and support, which is focused on a current situation of the individual employee and the entire team (Vaska, Brozmanová Gregorová \& Vrt́ová, 2020). 
Founders and headmasters of the kindergartens should look for ways and possibilities, that would lead to the prevention or minimization of the consequences of burnout syndrome in pedagogical staff, to look for ways to increase the efficiency and quality of teaching and pedagogical work (Baran \& al.,2010, Darius et al., 2021).

Future research will focus on evaluating the effectiveness of selected intervention strategies that could reduce the incidence of burnout syndrome in teachers and teaching assistants in special kindergartens.

\section{References}

[1] Aboagye, M. O., Qin, J., Qayyum, A., Antwi, C. O., Jababu, Y., \& Affum-Osei, E. (2018). Teacher burnout in pre-schools: A cross-cultural factorial validity, measurement invariance and latent mean comparison of the Maslach Burnout Inventory, Educators Survey (MBI-ES). Children and Youth Services Review, 94, 186197. DOI: $10.1016 /$ j.childyouth.2018.09.041

[2] Baran, G., Bıçakçı, M. Y., İnci, F., Öngör, M., Ceran, A., \& Atar, G. (2010). Analysis of burnout levels of teacher. Procedia-Social and Behavioral Sciences, 975-980. https://doi.org/10.1016/i.sbspro.2010.12.270

[3] Carson, R. L., Plemmons, S., Templin, T. J., \& Weiss, H. M. (2011). "You are who you are:" A mixed-method study of affectivity and emotion regulation in curbing teacher burnout. In G. M. Reevy \& E. Frydenberg (Eds.), Personality, stress, and coping: Implications for education (pp. 239-265). IAP Information Age Publishing.

[4] Cohen, J. (1988). Statistical power analysis for the behavioral science. Erlbaum

[5] Clipa, O., \& Boghean, A. (2015) Stress Factors and Solutions for the Phenomenon of Burnout of Preschool Teachers. Procedia - Social and Behavioral Sciences, 180, 907-915.

[6] Darius, S., Hohmann, C. B., Siegel, L., \& Böckelmann, I. (2021). Relationship between burnout risk and individual stress processing strategies in kindergarten teachers. [Zusammenhang zwischen dem BurnoutRisiko und individuellen Stressverarbeitungsstrategien bei Kindergartenerzieherinnen] PPmP Psychotherapie Psychosomatik Medizinische Psychologie, 71(6), 230-236. doi:10.1055/a-1376-6962

[7] De Stasio, S., Fiorilli, C., Benevene, P., Uusitalo-Malmivaara, L. \& Chiacchio, C.D. (2017), Burnout in special needs teachers at kindergarten and primary school: investigating the role of personal resources and work wellbeing. Psychology in the Schools, 54, 472-486. https://doi.org/10.100 2/pits.22013

[8] Hendl, J. (2012). Přehled statistických metod: analýza a metaanalýza dat. Portál

[9] Chráska, M. (2016). Metody pedagogického výzkumu: základy kvantitativního výzkumu. Grada

[10] Chrzanowska, I. (2019). Inclusive education in the opinion of the teachers from special pre-schools, regarding the chances of success of the inclusive actions towards particular groups of students, education participants, and teachers' seniority. Interdyscyplinarne Konteksty Pedagogiki Specjalnej, (25), 127-149.

[11] Jeung, D.-Y., Kim, C. \& Changs, S.-J., (2018). Emotional Labor and Burnout: A Review of the Literature. Yonsei Medical Journal, 59, 187. DOI:10.3349/ymj.2018.59.2.187

[12] Ji D and Yue Y (2020) Relationship Between Kindergarten Organizational Climate and Teacher Burnout: Work- Family Conflict as a Mediator. Front. Psychiatry 11:408. doi: 10.3389/fpsyt.2020.00408

[13] Kebza, V., \& Šolcová, I. (2008). Syndrom vyhoření: rekapitulace současného stavu poznání a perspektivy do budoucna. Československá psychologie, 52(4), 351-365.

[14] Kendíková, J. (2016). Předškolák se speciálními vzdělávacími potřebami. Raabe.

[15] Kokkinos, C.M. (2007), Job stressors, personality and burnout in primary school teachers. British Journal of Educational Psychology, 77, 229-243. https://doi.org/10.1348/000709905X90344 
[16] Klotz, J. (1963). Small Sample Power and Efficiency for the One Sample Wilcoxon and Normal Scores Tests. Annals of Mathematical Statistics, 34(2), 624-632. DOI: 10.1214/aoms/1177704175

[17] Křivohlavý, J. (1998). Jak neztratit nadšení. Grada.

[18] Levicka, J., Levicka, K., Banovcinova, A., \& Kovalcikova, N. (2018). Several Risks Related to the Introduction of an Early Intervention Service in the Slovak Republic. ACTA MISSIOLOGICA, 12(2), 106-119.

[19] Mahmoodi-Shahrebabaki, M. (2018). Teacher burnout. The TESOL encyclopedia of English language teaching, 1-8. https://doi.org/10.1002/9781118784235.eelt0964

[20] Maslach, C. (2015). Burnout, Psychology of, In J. D. Wright (Ed.), International Encyclopedia of the Social \& Behavioral Sciences (Second Edition), (pp. 929-932). DOI: 10.1016/B978-0-08-097086-8.26009-1. (https://www.sciencedirect.com/science/article/pii/B9780080970868260091)

[21] Němec, Z., Šimáčková-Laurenčíková, K., \& Hájková, V. (2014). Asistent pedagoga v inkluzivní škole. Vydavatelství PedF UK.

[22] Němec, Z., Šimáčková-Laurenčíková, K., Hájková, V., \& Strnadová, I. (2015). 'When I need to do something else with the other children, then I can rely on her': teaching assistants working with socially disadvantaged students. European Journal of Special Needs Education, 30(4), 459-473.

[23] Nur, A.R. \& Seung-II, N. (2020). An integrative review of the models for teacher expertise and career development. European Journal of Teacher Education, 43(3), 428-451. DOI: $10.1080 / 02619768.2020 .1728740$

[24] Pavlidou, K., Alevriadou, A., \& Antoniou, A. S. (2020). Professional burnout in general and special education teachers: the role of interpersonal coping strategies. European Journal of Special Needs Education, 1-15.

[25] Pines, A. M. (2002). Teacher burnout: A psychodynamic existential perspective. Teachers and Teaching: Theory and Practice, 8(2), 121-140. https://doi.org/10.1080/13540600220127331

[26] Pines, A. M., \& Keinan, G. (2005). Stress and burnout: The significant difference. Personality and Individual Differences, 39(3), 625-635. https://doi.org/10.1016/j.paid.2005.02.009

[27] Robinson, O.P., Bridges, S.A., Rollins, L.H. \& Schumacker, R.E., (2019). A study of the relation between special education burnout and job satisfaction. J Res Spec Educ Needs, 19, 295-303.

[28] Sheridan, P. K., Reeve, D., \& Evans, G. (2014). Understanding teaching assistants' assessment of individual teamwork performance. In 2014 ASEE Annual Conference \& Exposition (pp. 24-1293).

[29] Schonfeld, I. S., \& Bianchi, R., (2016). Burnout and Depression: Two Entities or One? J Clin Psychol., 72(1), 22-37.

[30] Sinclair, C., Mclnerney, D., \& Dowson, M. (2006). Motivations to teach: Psychometric perspectives across the first semester of teacher education. Teachers College Record, 108(6), 1132-1154.

[31] Smetáčková, I. (2019). Zpráva z dotazníkového šetření "Syndrom vyhoření mezi učitelkami a učiteli mateřských škol". https://www.edukacnilaborator.cz/vyhoreni

[32] Soukup, P., Trahorsch, P., \& Chytrý, V. (2021). Míry věcné významnosti s intervaly spolehlivosti a ukázky jejich využití v pedagogické praxi. Studia Paedagogica, 26(3), 131-166. doi:http://dx.doi.org/10.5817/SP2021-3-6

[33] Tasic, R., Rajovic N, Pavlovic V, Djikanovic B, Masic S, Velickovic I, et al. (2020) Nursery teachers in preschool institutions facing burnout: Are personality traits attributing to its development? PLOS ONE, 15(11). https://doi.org/10.1371/journal.pone.0242562 
[34] Teplá, M., Felcmanová, L., \& Němec, Z. (2019). Asistent pedagoga: jak efektivně zavést pozici asistenta pedagoga ve školách. Dashöfer.

[35] Truhlářová, Z., Štěch, O., Vosečková, A., Klímová, B., \& Kuča, K. (2020). Assessment of Mental Burden of Family Caregivers of Persons with Health Disabilities in the Czech Republic. Social sciences, 9(6), "Article number 95". https://doi.org/10.3390/socsci9060095

[36] Vaus, D. A. (1990): Surveys in Social Research. Unwin Hyman, London, p.182. In. Mareš, P. Rabušic, L. (2002): Měření (síly) asociace mezi dvěma spojitými proměnnými: korelační koeficienty a grafy

[37] Vaska, L., Brozmanová Gregorová, A., \& Vrt́ová, J. (2020). Modely supervízie organizace - výzkumné reflexe. Bellianum.

[38] Zákon č. 561/2004 Sb. Zákon o předškolním, základním, středním, vyšším odborném a jiném vzdělávání (školský zákon) v platném znění (online, cit. 9.10.2021), https://www.zakonyprolidi.cz/cs/2004-561 